\title{
Species composition, richness and nestedness of lizard assemblages from Restinga habitats along the brazilian coast
}

\author{
Rocha, CFD ${ }^{a *}$, Vrcibradic, D. ${ }^{b}$, Kiefer MC. ${ }^{c}$, Menezes, VA. ${ }^{a}$, Fontes, AF. ${ }^{a}$, Hatano, FH. ${ }^{d}$, \\ Galdino, CAB. ${ }^{e}$, Bergallo, HG. ${ }^{a}$ and Van Sluys, M. $^{a}$

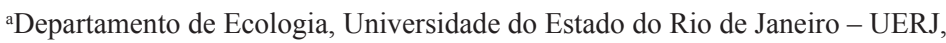 \\ Rua São Francisco Xavier, 524, CEP 20550-011, Rio de Janeiro, RJ, Brazil

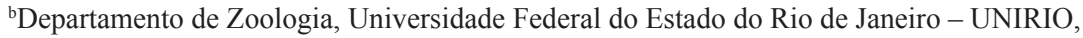 \\ Av. Pasteur 458, Urca, CEP 22240-290, Rio de Janeiro, RJ, Brazil

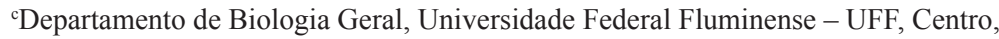 \\ CP 100436, CEP 24020-971, Niterói, RJ, Brazil \\ 'Instituto Socioambiental e dos Recursos Hídricos - ISARH, Universidade Federal Rural da Amazônia - UFRA, \\ Av. Presidente Tancredo Neves, 2501, Montese, CEP 66.077-901, Belém, PA, Brazil \\ ePrograma de Pós-Graduação em Zoologia, Pontifícia Universidade Católica de Minas Gerais - PUC-Minas, \\ Av. Dom José Gaspar, 500, CEP 30535-610, Belo Horizonte, MG, Brazil \\ *e-mail: cfdrocha@gmail.com
}

Received August 27, 2012 - Accepted February 20, 2013 - Distributed May 31, 2014

(With 1 figure)

\begin{abstract}
Habitat fragmentation is well known to adversely affect species living in the remaining, relatively isolated, habitat patches, especially for those having small range size and low density. This negative effect has been critical in coastal resting habitats. We analysed the lizard composition and richness of restinga habitats in 16 restinga habitats encompassing three Brazilian states (Rio de Janeiro, Espírito Santo and Bahia) and more than 1500km of the Brazilian coast in order to evaluate if the loss of lizard species following habitat reduction occur in a nested pattern or at random, using the "Nestedness Temperature Calculator" to analyse the distribution pattern of lizard species among the restingas studied. We also estimated the potential capacity that each restinga has to maintain lizard species. Eleven lizard species were recorded in the restingas, although not all species occurred in all areas. The restinga with the richest lizard fauna was Guriri (eight species) whereas the restinga with the lowest richness was Praia do Sul (located at Ilha Grande, a large coastal island). Among the restingas analysed, Jurubatiba, Guriri, Maricá and Praia das Neves, were the most hospitable for lizards. The matrix community temperature of the lizard assemblages was $20.49^{\circ}(=\mathrm{P}<0.00001 ; 5000$ randomisations; randomisation temperature $=51.45^{\circ} \pm 7.18^{\circ} \mathrm{SD}$ ), indicating that lizard assemblages in the coastal restingas exhibited a considerable nested structure. The degree in which an area is hospitable for different assemblages could be used to suggest those with greater value of conservation. We concluded that lizard assemblages in coastal restingas occur at a considerable level of ordination in restinga habitats and that some restinga areas such as Jurubatiba, Guriri, Maricá and Praia das Neves are quite important to preserve lizard diversity of restinga environments.
\end{abstract}

Keywords: assemblages, Brazil, lizard, nestedness, restinga.

\section{Composição de species, riqueza e grau de aninhamento de assmbléias de lagartos em habitats de Restingas ao longo da costa brasileira}

\begin{abstract}
Resumo
A fragmentação dos habitats constitui um importante fator bem conhecido por afetar negativamente as espécies que vivem em porções relativamente isoladas de habitats ou de de manchas de hábitat e, especificamente para aquelas que possuem menores extensões de área e menores densidades populacionais. Este efeito negativo tem sido crítico nos habitats de restingas. Nós analisamos a composição e a riqueza de lagartos de habitats de restinga em 16 áreas de restingas, abrangendo três estados brasileiros (Rio de Janeiro, Espírito Santo e Bahia), ao longo de mais de $1500 \mathrm{~km}$ da costa brasileira, visando avaliar se a perda de espécies de lagartos acompanharia a redução de habitat seguindo um padrão aninhado ou de forma aleatório, com uso do programa "Nestedness Temperature Calculator" para analisar o padrão de distribuição de espécies de lagartos entre as restingas estudadas. Estimamos também a capacidade potencial de cada área de restinga em manter as espécies de lagartos. Onze espécies de lagartos foram registradas nas restingas, embora nem todas as espécies tenham ocorrido em todas as áreas amostradas. A restinga com a maior riqueza de lagartos foi Guriri (oito espécies), enquanto a restinga com a menor riqueza foi a da Praia do Sul (localizada na Ilha Grande, uma
\end{abstract}


grande ilha costeira no sudeste do Brasil). Entre as restingas analisadas, Jurubatiba, Guriri, Maricá e Praia das Neves, foram as mais favoráveis para os lagartos. A temperatura da matriz da comunidade de lagartos foi de $20.49^{\circ} \mathrm{C}(=\mathrm{P}$ $<0,00001 ; 5000$ aleatorizações; temperatura randomizada $=51,45^{\circ} \mathrm{C}+7.18^{\circ} \mathrm{C} \mathrm{SD}$ ), o que indicou que as assembleias de lagartos nas restingas costeiras teve uma estrutura considerável aninhada. O grau segundo o qual uma área é mais favorável para diferentes assembléias pode ser utilizado como parâmetro para agregar maior valor de conservação desta área. Concluímos que as assembléias de lagartos nas restingas costeiras ocorreram em um considerável nível de ordenação e que algumas áreas de restinga como Jurubatiba, Guriri, Maricá e Praia das Neves são importantes e estratégicas para preservar a diversidade de lagartos de ambientes de restinga.

Palavras-chave: comunidades, Brasil, lagartos, aninhamento, restinga.

\section{Introduction}

Habitat fragmentation is well known to adversely affect species living in the remaining, relatively isolated, habitat patches, especially for those having small range size and low density (Foster, 1980; Terborgh and Winter, 1983; Fahrig, 2003). Because habitat fragmentation may differentially affect the species within an assemblage, the loss of species does not necessarily occur at random, but may occur in a nested pattern (Atmar and Patterson, 1993, 1995). Assemblages are nested when species present at species-poor sites are non-random subsets of the species present in species-rich areas (Cutler, 1991; Atmar and Patterson, 1993; Maron et al., 2004; Fischer and Lindenmayer, 2005a, b). Different factors including extinction, colonisation, habitat, and niche structure may cause these nested patterns, and some degree of nestedness appears to be the rule in nature (Wright et al., 1998; Patterson and Atmar, 2000).

The eastern coast of Brazil has been intensively occupied and modified by humans in the last five centuries and is currently the most densely populated region of the country (Rocha et al., 2003). Most coastal areas in Brazil are dominated by sand dune habitats covered with herbaceous and shrubby vegetation, known as "restingas" (Suguio and Tessler, 1984). The restingas are part of the Atlantic rainforest biome (Eiten, 1992), which is one of the so-called biodiversity hotspots (Mittermeier et al., 2005). Many restingas were naturally isolated from each other as a result of topography (Suguio and Tessler, 1984). Additionally, as a consequence of the disturbances continuously imposed to restinga habitats, most of their original area has been degraded and a large portion of it has been lost (Rocha et al., 2007). Presently, most of the eastern Brazilian coastal is composed of remnants of restinga habitats separated by human-dominated landscapes (Rocha et al., 2007). Different lizards assemblages are found in the remaining restingas (Rocha, 2000) and some of such fragments contain an important set of endemic and threatened vertebrate species (Rocha et al., 2005).

In this study we analysed the lizard composition and richness of restinga habitats in order to evaluate if the loss of lizard species following habitat reduction occur in a nested pattern or at random. We also estimated the potential capacity that each restinga has to maintain lizard species (that is, the hospitality of each area, sensu Patterson and Atmar , 2000).

\section{Study Areas and Methods}

We intensively sampled and recorded lizards in 16 restinga habitats encompassing three Brazilian states (Rio de Janeiro, Espírito Santo and Bahia) and more than $1500 \mathrm{~km}$ of the Brazilian coast (Figure 1, Table 1). Restingas are Quaternary sand dune habitats characterised by sparse, mostly xerophilous shrubby and herbaceous vegetation (Suguio and Tessler, 1984). These habitats vary both floristically (Araújo and Henriques, 1984) and structurally (Rocha and Bergallo, 1997). Estimates in Nova Viçosa, Itaúnas, Linhares, Pontal do Ipiranga, Marataízes, Neves (Espírito Santo state), and Grumari (Rio de Janeiro state) were made from December to January 1996 whereas Trancoso, Prado (Bahia state), Guriri, Setiba (Espírito Santo state), Grussaí, Macaé, Maricá, Massambaba and Praia do Sul (Rio de Janeiro state) were sampled from November 1999 to February 2000. The general geographical location of each area was recorded using a Garmin II GPS set to WGS-84 datum.

We intensively sampled each restinga during four consecutive days through Time-constrained Visual Encounter Surveys (Crump and Scott Junior, 1994), keeping sampling effort equivalent (30 min transectation within each one hour interval from dusk in the morning to dusk in the night, totaling about six and half hour of search/day). Searches were undertaken from 06:00 to 19:00h which includes the peaks of activity of most lizards of restingas (Araújo, 1984; Rocha, 1988; Bergallo and Rocha, 1993; Teixeira-Filho et al., 1995; Vrcibradic and Rocha, 1996; Zaluar and Rocha, 2000; Hatano et al., 2001) and the start of activity of the only nocturnal species in the restingas the invasive Hemidactylus mabouia (Moreaú de Jonnés, 1818) (Rocha et al., 2002). Weather conditions during sampling were as similar as possible. During sampling we carefully searched for lizards in all different potential microhabitats, such as the border and interior of bushes, on trees and shrubs, on the leaf litter and on bromeliads. In order to reduce differences due to vegetation structure, we searched for lizards in areas similar in physiognomy, characterised by sandy soil covered predominantly with thickets of shrubs and herbaceous vegetation at similar distances from the sea (approximately $200 \mathrm{~m}$ ). Linhares was an exception because it is an isolated patch of restinga located about $12 \mathrm{~km}$ inland from the coast (Rocha et al., 1997). 


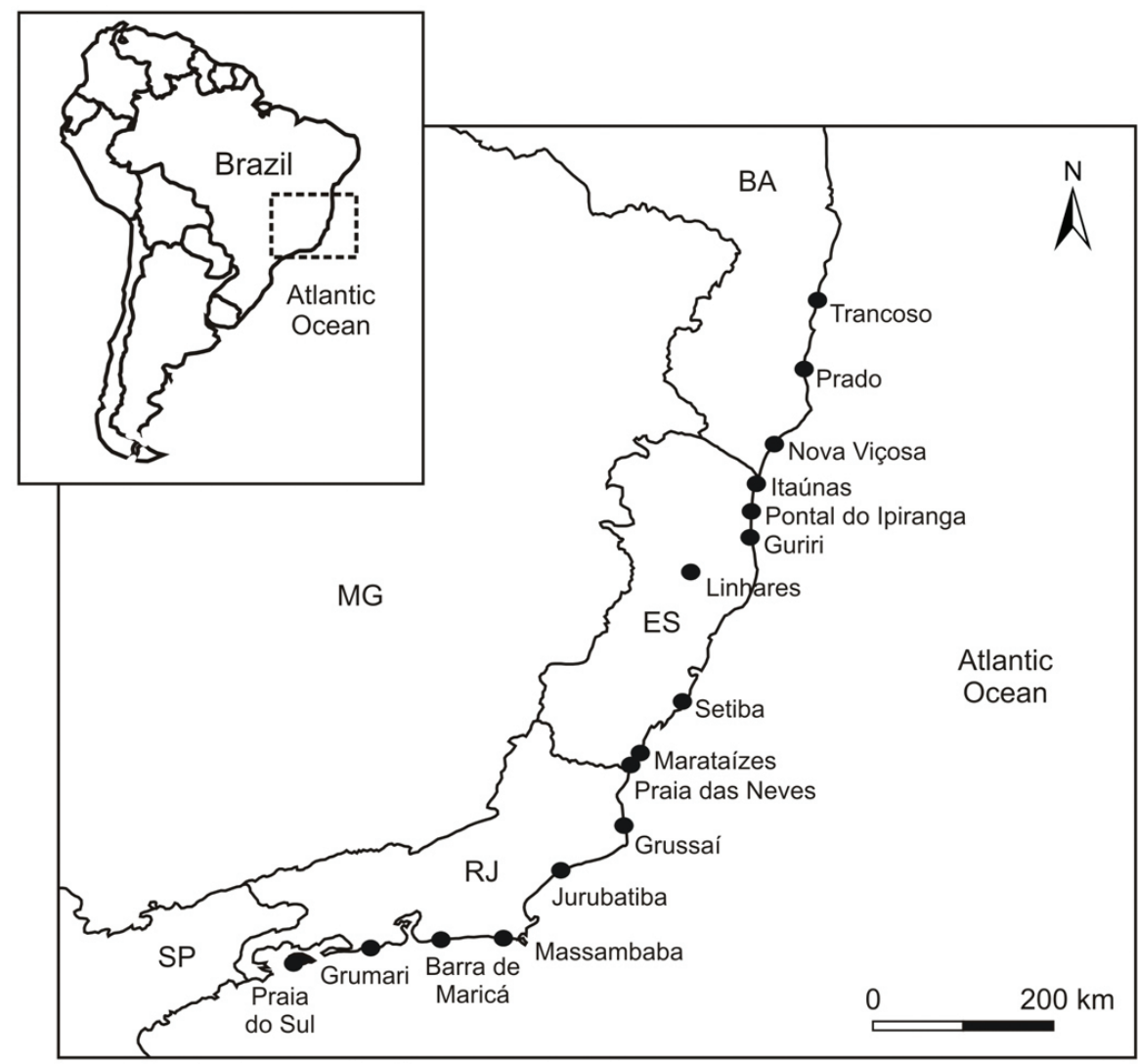

Figure 1. Map showing the sampling localities at 16 restinga habitats in Rio de Janeiro, Espírito Santo and Bahia states, Brazil.

Table 1. Restingas sampled for lizard species in 16 restinga areas in the states of Rio de Janeiro, Espirito Santo and Bahia, eastern Brazilian coast. Coordinates based on datum WGS-84.

\begin{tabular}{ll}
\hline \multicolumn{1}{c}{ Restingas } & \multicolumn{1}{c}{ Coordinates } \\
\hline Rio de Janeiro & \\
Praia do Sul & $23^{\circ} 10^{\prime} \mathrm{S} ; 44^{\circ} 18^{\prime} \mathrm{W}$ \\
Grumari & $23^{\circ} 03^{\prime} \mathrm{S} ; 43^{\circ} 32^{\prime} \mathrm{W}$ \\
Barra de Maricá & $22^{\circ} 57^{\prime} \mathrm{S} ; 42^{\circ} 50^{\prime} \mathrm{W}$ \\
Massambaba & $22^{\circ} 56^{\prime} \mathrm{S} ; 42^{\circ} 12^{\prime} \mathrm{W}$ \\
Grussaí & $21^{\circ} 44^{\prime} \mathrm{S} ; 41^{\circ} 02^{\prime} \mathrm{W}$ \\
Jurubatiba & $22^{\circ} 17^{\prime} \mathrm{S} ; 41^{\circ} 41^{\prime} \mathrm{W}$ \\
Espírito Santo & \\
Neves & $21^{\circ} 15^{\prime} \mathrm{S} ; 40^{\circ} 58^{\prime} \mathrm{W}$ \\
Marataízes & $21^{\circ} 05^{\prime} \mathrm{S} ; 40^{\circ} 51^{\prime} \mathrm{W}$ \\
Setiba & $20^{\circ} 35^{\prime} \mathrm{S} ; 40^{\circ} 27^{\prime} \mathrm{W}$ \\
Guriri & $18^{\circ} 41^{\prime} \mathrm{S} ; 39^{\circ} 45^{\prime} \mathrm{W}$ \\
Linhares & $19^{\circ} 18^{\prime} \mathrm{S} ; 40^{\circ} 19^{\prime} \mathrm{W}$ \\
Pontal do Ipiranga & $19^{\circ} 10^{\prime} \mathrm{S} ; 39^{\circ} 45^{\prime} \mathrm{W}$ \\
Itaúnas & $18^{\circ} 24^{\prime} \mathrm{S} ; 39^{\circ} 43^{\prime} \mathrm{W}$ \\
Bahia & \\
Nova Viçosa & $18^{\circ} 05^{\prime} \mathrm{S} ; 39^{\circ} 33^{\prime} \mathrm{W}$ \\
Prado & $17^{\circ} 18^{\prime} \mathrm{S} ; 39^{\circ} 13^{\prime} \mathrm{W}$ \\
Trancoso & $16^{\circ} 39^{\prime} \mathrm{S} ; 39^{\circ} 05^{\prime} \mathrm{W}$ \\
\hline
\end{tabular}

We used the "Nestedness Temperature Calculator" of Atmar and Patterson $(1993,1995)$ to analyse the distribution pattern of lizard species among the restingas. This method analyses the matrix of presence and absence of species and calculates its "temperature", which indicates the level of order or disorder of the matrix. The lower the temperature of the matrix (level of nestedness of the system), the lower is its disorder and less stochastic is the distribution of the species in the studied assemblage. For this analysis we used 5000 randomisations. We also evaluated the capacity that each restinga has to maintain lizard species ("hospitality"), and potential areas to be preserved (Atmar and Patterson, 1993, 1995).

\section{Results and Discussion}

Eleven lizard species were recorded in the restingas, although not all species occurred in all areas (Table 2). Of the species recorded four were of the family Teiidae [Ameiva ameiva (Linnaeus, 1758), Cnemidophorus littoralis Rocha, Araújo, Vrcibradic and Costa, 2000, C. nativo Rocha, Bergallo and Peccinini-Seale, 1997 and Kentropix calcarata Spix, 1825], three were gekkotans [Gymnodactylus darwini (Gray, 1845), Bogertia lutzae Loveridge, 1941 and Hemidactylus mabouia], two Scincidae [Mabuya agilis (Raddi, 1823) and M. macrorhyncha Hoge, 1947], one 
Table 2. Lizard species composition and richness found during samplings in 16 restinga areas along $1500 \mathrm{~km}$ of the Brazilian coast of the states of Rio de Janeiro, Espírito Santo and Bahia. TT = Tropidurus torquatus; LL = Liolaemus lutzae; AA = Ameiva ameiva $; \mathrm{CL}=$ Cnemidophorus littoralis; $\mathrm{CN}=$ Cnemidophorus nativo; $\mathrm{MA}=$ Mabuya agilis; $\mathrm{MM}=$ Mabuia macrorhyncha $; \mathrm{GD}=$ Gymnodaqctylus darwinii $; \mathrm{KC}=$ Kentropix calcarata $; \mathrm{HM}=$ Hemidactylus mabouia .

\begin{tabular}{|c|c|c|c|c|c|c|c|c|c|c|}
\hline $\begin{array}{l}\text { LIZARD SPECIES } \\
\text { RESTINGA AREAS }\end{array}$ & TT & $\mathbf{L L}$ & $\mathbf{A A}$ & $\mathbf{C L}$ & $\mathrm{CN}$ & MA & MM & GD & $\mathrm{KC}$ & HM \\
\hline Praia do Sul & & & & & & $\mathrm{X}$ & & & & \\
\hline Grumari & $\mathrm{X}$ & $\mathrm{X}$ & $\mathrm{X}$ & & & $\mathrm{X}$ & $\mathrm{X}$ & & & $\mathrm{X}$ \\
\hline Barra de Maricá & X & $X$ & $\mathrm{X}$ & $\mathrm{X}$ & & $\mathrm{X}$ & $\mathrm{X}$ & $\mathrm{X}$ & & $\mathrm{X}$ \\
\hline Massambaba & $\mathrm{X}$ & $\mathrm{X}$ & & & & $\mathrm{X}$ & $\mathrm{X}$ & $\mathrm{X}$ & & $\mathrm{X}$ \\
\hline Grussaí & $\mathrm{X}$ & & $\mathrm{X}$ & $\mathrm{X}$ & & $\mathrm{X}$ & $\mathrm{X}$ & & & $\mathrm{X}$ \\
\hline Jurubatiba & $\mathrm{X}$ & & $\mathrm{X}$ & $\mathrm{X}$ & & $\mathrm{X}$ & $\mathrm{X}$ & $\mathrm{X}$ & & $\mathrm{X}$ \\
\hline Neves & $\mathrm{X}$ & & $\mathrm{X}$ & & & $\mathrm{X}$ & $\mathrm{X}$ & & & $\mathrm{X}$ \\
\hline Marataízes & $\mathrm{X}$ & & $\mathrm{X}$ & & & & & & & \\
\hline Setiba & $\mathrm{X}$ & & $\mathrm{X}$ & & $\mathrm{X}$ & $\mathrm{X}$ & & & & \\
\hline Guriri & $\mathrm{X}$ & & & & $\mathrm{X}$ & $\mathrm{X}$ & $\mathrm{X}$ & $\mathrm{X}$ & $\mathrm{X}$ & $\mathrm{X}$ \\
\hline Linhares & $\mathrm{X}$ & & $\mathrm{X}$ & & $\mathrm{X}$ & $\mathrm{X}$ & & & $\mathrm{X}$ & \\
\hline Pontal do Ipiranga & $\mathrm{X}$ & & $\mathrm{X}$ & & & & & & & \\
\hline Itaúnas & $\mathrm{X}$ & & $\mathrm{X}$ & & $\mathrm{X}$ & $\mathrm{X}$ & & & & \\
\hline Nova Viçosa & $\mathrm{X}$ & & $\mathrm{X}$ & & $\mathrm{X}$ & $\mathrm{X}$ & & & & \\
\hline Prado & $\mathrm{X}$ & & $\mathrm{X}$ & & $\mathrm{X}$ & $\mathrm{X}$ & $\mathrm{X}$ & & & \\
\hline Trancoso & $\mathrm{X}$ & & $\mathrm{X}$ & & & & $\mathrm{X}$ & & & \\
\hline
\end{tabular}

Tropiduridae [Tropidurus torquatus (Wied, 1820)], and one Liolaemidae (Liolaemus lutzae Mertens, 1938). The restinga with the richest lizard fauna was Guriri (eight species) whereas the restinga with the lowest richness was Praia do Sul (located at Ilha Grande, a large coastal island), where only one species (M. agilis) was recorded during samplings. Most species were found in the diurnal transects except for H. mabouia (an exotic invasive species in Brazil; see Rocha and Bergallo, 2011; Rocha et al., 2011), which was found in the crepuscular/nocturnal ones. Some of the lizard species were present in most restingas (such as Tropidurus torquatus, Mabuya agilis) whereas others (e.g. Liolaemus lutzae, Cnemidophorus littoralis and C. nativo) were restricted to just a few areas. Tropidurus torquatus and Mabuya agilis are usually common and abundant lizard species in a wide array of habitats (Rocha and Bergallo, 1997; Rocha, 2000; Rocha et al., 2003, 2005). On the other hand, Liolaemus lutzae (Rocha et al., 2009), Cnemidophorus littoralis (Rocha et al. 2000) and C. nativo (Rocha et al. 1997) are endemic to restingas and have restricted distributions.

The matrix community temperature of the lizard assemblages was $20.49^{\circ}(=\mathrm{P}<0.00001 ; 5000$ randomisations; randomisation temperature $\left.=51.45 \pm 7.18^{\circ} \mathrm{SD}\right)$, indicating that lizard assemblages in the coastal restingas exhibited a considerable nested structure. In general, nested assemblages occur as a result of processes such as selective immigration or extinction, habitat nestedness and fragmentation (Fischer and Lindenmayer, 2005a, b). In the case of coastal restingas, the nested pattern of lizard assemblages may result in part from the degradation and fragmentation of restingas along the coast which led to the increasing isolation of these habitats (Rocha et al., 2007) and in part from the distinct geological histories of each area. However, our dataset does not allow distinguishing between these two putative causes for the nested pattern found. Nevertheless, the frogs assemblages in these restinga habitats were also nested (Rocha et al., 2008). Fragmented systems tend to exhibit distinctive patterns of species richness and species composition (Atmar and Patterson, 1995; Patterson and Atmar, 2000) and this was the tendency we found with the lizard assemblages.

Among the restingas analysed, Jurubatiba, Guriri, Maricá and Praia das Neves, were the most hospitable for lizards (Table 2). For frogs, Praia das Neves was also considered the most hospitable restinga in the eastern Brazilian coast (Rocha et al., 2008). The degree in which an area is hospitable for different assemblages could be used to suggest those with greater value of conservation. In the case of restinga lizards, the three endemic species were present in the restingas identified as most hospitable. However, at the same time, these areas are still not protected as conservation units, with the exception of Jurubatiba which is the only restinga already protected as a National Park in Brazil.

We concluded that lizard assemblages in coastal restingas occur at a considerable level of ordination in restinga habitats and that some restinga areas such as Jurubatiba, Guriri, Maricá and Praia das Neves are quite important to preserve lizard diversity of Brazilian restinga environments.

Acknowledgements - This study was supported by grants from the "Conselho Nacional do Desenvolvimento Científico e Tecnológico"- CNPq (processes No. 304791/2010-5 and 472287/2012-5) to CFDR, to M V (processes \# 
301401/04-7 and 307773/08-6), to M C Kiefer (processes \# $146442 / 1999-7$ and 150353/2003-0) and to HGB (processes \# 307715/2009-4). CFDR (process No. E-26/102.765/2012) and HGB (process No. E-26/103.016/2011) also benefitted from a grant from the "Fundação Carlos Chagas de Apoio à Pesquisa do Estado do Rio de Janeiro" - FAPERJ through the Programme "Cientistas do Nosso Estado". During this study VAM and AFF received a Graduate fellowship from $\mathrm{CNPq}$ and FAPERJ. VAM received a grant from FAPERJ (processes \# 100.005/2009).

\section{References}

ARAÚJO, AFB., 1984. Padrões de divisão de recursos em uma comunidade de lagartos de resting. In. LACERDA, LD., CERQUEIRA, R. and TURCQ, B. (Ed.). Restingas: origem, estrutura e processos. Niterói: CEUFF. p. 327-342.

ARAÚJO, DSD. and HENRIQUES, RPB., 1984. Análise florística das restingas do Estado do Rio de Janeiro. In. Lacerda, LD. Cerqueira, R. and Turcq, B. (Ed.). Restingas: origem, estrutura e processos. Niterói: CEUFF. p. 159-193.

ATMAR, W. and PATTERSON, BD., 1993. The measure of order and disorder in the distribution of species in fragmented habitats. Oecologia, vol. 96, no. 3, p. 373-382. http://dx.doi.org/10.1007/ BF00317508.

ATMAR, W. and PATTERSON, BD., 1995. The nestedness temperature calculator: a visual basic program including 294 presence-absence matrices. Chicago: AICS Research/University Park/Field Museum. Available from: <http://aics-research. com/nestedness/tempcalc.html>.

BERGALLO, HG. and ROCHA, CFD., 1993. Activity Patterns and Body Temperatures of Two Sympatric Lizards with Different Foraging Tactics in Southeastern Brazil. Amphibia-Reptilia, vol. 14, no. 7, p. 312-315. http://dx.doi.org/10.1163/156853893X00525.

CRUMP, ML. and SCOTT JUNIOR, NJ., 1994. Visual encounter surveys. In: HEYER, WR. et al. (Ed.). Measuring and Monitoring Biological Diversity: Standard Methods for Amphibians. Washington DC: Smithsonian Institution Press. p. 84-92.

CUTLER, A., 1991. Nested faunas and extinction in fragmented habitats. Conservation Biology, vol. 5, no. 4, p. 496-504. http:// dx.doi.org/10.1111/j.1523-1739.1991.tb00357.x.

EITEN, G., 1992. Natural Brazilian Vegetation Types and Their Causes. Anais da Academia Brasileira de Ciencias, vol. 64, p. 35-65.

FAHRIG, L., 2003. Effects of habitat fragmentation on biodiversity. Annual Review of Ecology and Systematics, vol. 34, no. 1, p. 487515. http://dx.doi.org/10.1146/annurev.ecolsys.34.011802.132419.

FISCHER, J. and LINDENMAYER, DB., 2005a. Perfectly nested or significantly nested - an important difference for conservation management. Oikos, vol. 109, no. 3, p. 485-494. http://dx.doi. org/10.1111/j.0030-1299.2005.13674.x.

FISCHER, J. and LINDENMAYER, DB., 2005b. Nestedness in fragmented landscapes: a case study on birds, arboreal marsupials and lizards. Journal of Biogeography, vol. 32, no. 10, p. 1737-1750. http://dx.doi.org/10.1111/j.1365-2699.2005.01319.x.

FOSTER, RB., 1980. Heterogeneity and disturbance in tropical vegetation. In SOULÉ, ME. and WICOX, BA. (Ed.). Conservation Biology: An evolutionary-ecological approach. Massachussets: Sinauer Assoc. Sunderland. p. 75-92.
HATANO, FH., VRCIBRADIC, D., GALDINO, CAB., CUNHABARROS, M., ROCHA, CF. and VAN SLUYS, M., 2001. Thermal ecology and activity patterns of the lizard community of the Restinga of Jurubatiba, Macaé, RJ. Brazilian Journal of Biology, vol. 61, no. 2, p. 287-294. PMid:11514896.

MARON, M., MAC NALLY, R., WATSON, DM. and LILL, A., 2004. Can the biotic nestedness matrix be used predictively? Oikos, vol. 106, p. 433-444. http://dx.doi.org/10.1111/j.00301299.2004.13199.x.

MITTERMEIER, RA., GIL, RP., HOFFMAN, M., PILGRIM, J., BROOKS, T., MITTERMEIER, CG., LAMOREUX, J. and FONSECA, GAB., 2005. Hotspots revisited: earth's biologically richest and most endangered terrestrial ecoregions. 2nd ed. Boston: University of Chicago Press/Conservation International. 392 p.

PATTERSON, BD. and ATMAR, W.,2000. Analyzing species composition in fragments. In RHEINWALD, G. (Ed.). Isolated vertebrate communities in the tropics. Germany: Bonner Zoologische Monographen 46. p. 9-24.

ROCHA, CFD., 1988. Ritmo de atividade e microclimatologia do habitat de Liolaemus lutzae (Sauria-Iguallidae). Anais do Seminário Regional de Ecologia, vol. 6, p. 269-281.

ROCHA, CFD.,2000. Biogeografia de répteis de restingas: distribuição, ocorrência e endemismos. In: ESTEVES, FA. and LACERDA, LD. (Ed.). Ecologia de Restingas e Lagoas Costeiras. Macaé: NUPEM/UFRJ. p. 99-116.

ROCHA, CFD. and BERGALLO, HG., 1997.

Intercommunity variation in the distribution of abundance of dominant lizard species in restinga habitats. Ciencia e Cultura, vol. 49 , no. 4 , p. $269-274$.

ROCHA, CF. and BERGALLO, HG., 2011. Occurrence and distribution of the exotic lizard Hemidactylus mabouia Moreau de Jonnès, 1818 in Ilha Grande, RJ, Brazil. Brazilian Journal of Biology, vol. 71, no. 2, p. 447-450. http://dx.doi.org/10.1590/ S1519-69842011000300014. PMid:21755162

ROCHA, CF., DUTRA, GF., VRCIBRADIC, D. and MENEZES, VA., 2002. The terrestrial reptile fauna of the Abrolhos Archipelago: species list and ecological aspects. Brazilian Journal of Biology, vol. 62 , no. 2, p. 285-291. http://dx.doi.org/10.1590/S151969842002000200013. PMid:12489402

ROCHA, CFD., BERGALLO, HG., ALVES, MAS. and VAN SLUYS, M., 2003. A biodiversidade nos grandes remanescentes florestais do Estado do Rio de Janeiro e nas restingas da Mata Atlântica. São Carlos: Rima Editora. 134 p.

ROCHA, CFD., VAN SLUYS, M., BERGALLO, HG. and ALVES, MAS., 2005. Endemic and threatened tetrapods in the restingas of the biodiversity corridors of Serra do Mar and of the Central da Mata Atlântica in eastern Brazil. Brazilian Journal of Biology, vol. 65, no. 1, p. 159-168. http://dx.doi.org/10.1590/ S1519-69842005000100019. PMid:16025914

ROCHA, CFD., BERGALLO, HG., VAN SLUYS, M., ALVES, M. and JAMEL, C., 2007. The remnants of restinga habitats in the Brazilian Atlantic Forest of Rio de Janeiro State, Brazil: habitat loss and risk of disappearance. Brazilian Journal of Biology, vol. 67, no. 2, p. 263-273. http://dx.doi.org/10.1590/ S1519-69842007000200011.

ROCHA, CFD., HATANO, FH., VRCIBRADIC, D. and VAN SLUYS, M., 2008. Frog species richness, composition and $\beta$-diversity in coastal Brazilian restinga habitats. Brazilian Journal 
of Biology, vol. 68, no. 1, p. 101-107. http://dx.doi.org/10.1590/ S1519-69842008000100014. PMid:18470383

ROCHA., CF., ANJOS, LA. and BERGALLO, HG., 2011. Conquering Brazil: the invasion by the exotic gekkonid lizard Hemidactylus mabouia (Squamata) in Brazilian natural environments. Zoologia, vol. 28, no. 6, p. 747-754. http://dx.doi.org/10.1590/ S1984-46702011000600007.

SUGUIO, K. and TESSLER, MG., 1984. Planícies de cordões litorâneos Quaternários do Brasil: Origem e nomenclatura. In LACERDA, LD., ARAÚJO, DSD., CERQUEIRA, R. and TURCQ, B. (Ed.). Restingas: origem, estrutura e processos. Niterói: Centro Editorial da Universidade Federal Fluminense. p. 32-56.

TEIXEIRA FILHO, PFP., ROCHA, CFD. and RIBAS, SC., 1995. Aspectos da Ecologia Termal e Uso do Habitat Por Cnemidophorus ocellifer (Sauria: Teiidae) Na Restinga de Maricá, Rj. Oecologia Brasiliensis, vol. 1, p. 155-165.
TERBORGH, JW. and WINTER., 1983. A method for siting parks and reserves with special reference to Colombia and Ecuador. Biological Conservation, vol. 27, no. 1, p. 45-58. http://dx.doi. org/10.1016/0006-3207(83)90005-8.

VRCIBRADIC, D. and ROCHA, CFD., 1996. Ecological differences in tropical sympatric skinks (Mabuya agilis and Mabuya macrorhyncha) in Southeastern Brazil. Journal of Herpetology, vol. 30 , no. 1 , p. 60-67.

WRIGHT, DV., PATTERSON, BD., MIKKELSON, GM., CUTLER, A. and ATMAR, W., 1998. A comparative analysis of nested subset patterns of species composition. Oecologia, vol. 113, p. 1-20.

ZALUAR, H. and ROCHA, CFD., 2000. Ecology of the wideforaging lizard Ameiva ameiva (Teiidae) in a sand dune habitat of southeast Brazil: ontogenetic, sexual and seasonal trends in food habits, activity, thermal biology and microhabitat use. Ciencia e Cultura, vol. 52, no. 2, p. 101-107. 